\title{
A existência como resultado de acasos em Quem ama não dorme, de Robert Schneider
}

\author{
[The existence as result of chances in Brother of sleep, by Robert Schneider] \\ http://dx.doi.org/10.11606/1982-88372339111
}

\author{
Rosani Umbach ${ }^{1}$ \\ Sabrina Pereira ${ }^{2}$
}

\begin{abstract}
Brother of sleep (Schlafes Bruder) is the first novel by the Austrian writer Robert Schneider, published in 1992. It tells the story of a music prodigy, who was born in a small village at the beginning of the nineteenth century. This paper aims to reflect on the series of obstacles that stop the protagonist, Elias Alder, from achieving professional and personal success, given the limitations of the community. The novel condenses modern and post-modern characteristics, such as the identity fragmentation, the irony, the estrangement and the breaking of narrative linearity.
\end{abstract}

Keywords: Robert Schneider; fragmentation; unusual; irony.

Resumo: Quem ama não dorme (Schlafes Bruder) é o primeiro romance do escritor austríaco Robert Schneider, publicado em 1992. Ele conta a história de um prodígio da música, nascido em um vilarejo no início do século XIX. Este artigo tem como objetivo refletir sobre a série de empecilhos que impedem o protagonista, Elias Alder, de alcançar sucesso profissional e pessoal, tendo em vista as limitações da comunidade. O romance condensa características modernas e pósmodernas, como a fragmentação identitária, a ironia, o estranhamento e a quebra da linearidade narrativa.

Palavras-chave: Robert Schneider; fragmentação; insólito; ironia.

\section{Introdução}

Publicado em 1992, o romance Quem ama não dorme, primeiro do escritor Robert Schneider, possibilita refletir sobre se basta a um indivíduo ter talento ou se outros fatores devem coincidir com a existência do dom para que o sujeito alcance pleno desenvolvimento e felicidade. O romance conta a história de Elias Alder, um músico

\footnotetext{
${ }^{1}$ Universidade Federal de Santa Maria, Av. Roraima 1000, Prédio 16, Camobi, Santa Maria, RS, 97105302, Brasil. E-mail: rosani.umbach@ gmail.com. ORCID: 0000-0002-8221-1869

${ }^{2}$ Universidade Federal de Santa Maria, Av. Roraima 1000, Prédio 16, Camobi, Santa Maria, RS, 97105302, Brasil. E-mail: sabrinasiqueir@yahoo.com.br. ORCID: 0000-0003-3026-4739
}

\section{(cc) BY-NC}


UMBACH, R.; PEREIRA, S. - A existência como resultado de acasos

genial cujo talento é sufocado pela inveja e mesquinhez da pequena localidade em que vive. Fazendo uso de características do Modernismo e do Pós-Modernismo, o autor alia a indiferença da natureza e a ausência de chances para culminar no fracasso do protagonista, que é confrontado com duas grandes questões: o talento e o amor. Quais são os empecilhos para que ele obtenha sucesso nessas duas instâncias? Por que o talento e o amor de Elias, apesar de imensos, não culminam em notoriedade e felicidade?

Os protagonistas do Modernismo caracterizam-se pela heroicidade dotada de singularidades e complexidades humanas, cujo caminho pode girar em torno da busca pelo vínculo com o grupo e do pertencimento a ele, tendo nisso uma possibilidade de encontrar sentido na existência. Já para o Pós-Modernismo, uma das características fundamentais é a sensação de desintegração dos valores básicos sociais, nacionais e humanistas. Os vínculos são mostrados como esvaziados de significado e a desconexão é uma condição básica de cada ser humano. Elias Alder é um protagonista vítima da desintegração dos valores sociais em sua comunidade e do esvaziamento dos vínculos e laços de afeto com a família. No entanto, como um herói moderno, ele busca o sentido para sua vida a partir da tentativa de pertencimento, que para ele passa pela realização do amor.

No primeiro capítulo de Quem ama não dorme, que é de apenas uma página, o narrador informa sobre o suicídio do protagonista, aos 22 anos, infeliz por um amor não correspondido. Como antecipa o final, a narrativa concentra-se nos prováveis "como" e "por que" Johannes Elias Alder põe termo à própria vida. O que segue é a história de alguém que nasce excepcionalmente sensível e talentoso, em princípios do século XIX, no vilarejo austríaco de Eschberg. Dono de uma voz peculiar desde o nascimento, aos cinco anos Elias vivencia um fenômeno que lhe desenvolve ouvido absoluto, dom pelo qual consegue escutar os batimentos cardíacos do feto que acredita ser a mulher destinada a ele. Além da audição que o capacita como musicista autodidata, o fenômeno marca Elias com olhos amarelos, aparência estranha e puberdade precoce.

\section{Aspectos da Modernidade tardia}

Em seu texto sobre o romance de Robert Schneider, Lars Schmeink (2004) propõe uma leitura pós-moderna da obra, rebatendo críticas anteriores de que se trataria de literatura 
UMBACH, R.; PEREIRA, S. - A existência como resultado de acasos

trivial ou um fenômeno kitsch. Com base nos estudos de Rainer Moritz $(1996,1999)$ e outros, Schmeink afirma que a crítica literária especializada comprovou, em numerosas análises e interpretações, que Quem ama não dorme é composto de elementos e gêneros diversos e pode ser lido como hagiografia, romance de gênio ou ainda como crônica ironizante da aldeia (SCHMEINK 2004: 49). Entretanto, ainda que apresente marcas pósmodernas, o romance contém igualmente aspectos da Modernidade tardia.

Quanto às características do Modernismo, Quem ama não dorme tem em Elias Alder um herói autêntico. É dotado de singularidades, mas ainda permanece um herói cujo caminho e história giram em torno da busca pelo vínculo com o grupo e do pertencimento a este grupo, como forma de vislumbrar sentido na existência. Quanto às características do Pós-Modernismo, identifica-se tessitura intertextual, narrador opinativo, ironia, narrativa e personagens fragmentários, além do pano de fundo permeado pelo insólito, que provoca estranhamento e se contrapõe à verossimilhança buscada pelos romances realistas.

Intertextualidade é uma das formas de expressão da corrente pós-modernista. As alusões a outros textos acontecem no romance de Schneider, assim como as repetições, em versões diferentes, dos mesmos casos e acontecimentos dentro da trama. O segundo capítulo é exemplo de repetição de um acontecimento na história. Intitulado "O último capítulo", conta sobre o desfecho do vilarejo de Eschberg e sobre a morte do último Alder, que levanta a hipótese de que a obstinação de Elias em não dormir poderia ser um traço hereditário e negativo da constante consanguinidade praticada por gerações no povoado, já que Cosmas Alder também morre por iniciativa própria, a de não mais comer. A hipótese de uma inclinação suicida ser característica genética levanta a teoria de um vínculo inevitável da humanidade com a natureza silenciosa e poderosa, ou com a Terra como um organismo vivo e obstinado e cujo objetivo independe de qualquer ação ou traço humano, sobrepondo-se a este, seja ele bom ou ruim, já que se manifesta tanto no brilhante Elias quanto no teimoso Cosmas.

Como exemplo de referências a outros textos, o romance de Schneider alude a $O s$ sofrimentos do jovem Werther, de Goethe, pela história de um jovem preterido pela amada que se suicida, e a A metamorfose, de Franz Kafka, uma vez que o protagonista Johannes Elias é segregado pela família e trancado no quarto, de forma semelhante àquela em que 
UMBACH, R.; PEREIRA, S. - A existência como resultado de acasos

Gregor Samsa é confinado ao espaço de seu dormitório e não conta com compreensão ou afeto por parte dos familiares:

Depois de ter Deus revelado a Elias, de forma tão milagrosa quão terrível, o mundo dos sons, no rapaz fez-se silêncio. Somente sobre o rapaz é que não havia meio de se fazer silêncio. Por isso, o casal Alder escondia-o, receoso, da exposição pública, enclausurando-o, a poder de bofetões, lambadas e bordoadas, no quarto do qual jamais podia sair sem autorização (SCHNEIDER 1999: 38).

A fragmentação é outra das características marcantes da literatura pós-modernista. Em Quem ama não dorme, essa característica está presente ao longo da narrativa em pequenas histórias que não ganham continuidade e que pouco interferem com a narrativa principal, que trata da vida de Elias. A fragmentação está na não linearidade do tempo diegético e também na ausência de vínculos do protagonista e de outras personagens que permanecem outsiders no espaço dramatizado.

Podendo estar relacionados à narrativa fragmentária, os elementos fantásticos são característicos da ficção pós-modernista, que busca desconstruir a solidez da realidade e cujos fundamentos servem ao processo de aquisição de sentido. Algumas passagens de Quem ama não dorme podem ser classificadas como realismo mágico ou fantástico, já que extrapolam as inferências ao realismo e apresentam ações que dificilmente poderiam ser interpretadas pela razão. O principal exemplo de realismo fantástico da obra é o fenômeno em que a natureza, representada pela pedra da cachoeira, chama Elias e ali acontece a expansão de sua audição de forma supranatural, uma vez que escuta até batimentos cardíacos de um feto e passa a conseguir se comunicar nas ondas sonoras audíveis apenas pelos animais. É irônico que o elemento da natureza capaz de ampliar os "poderes" de Elias seja uma pedra, parte da natureza inorgânica, sujeita à lei do silêncio e da fixação. Referências a características da realidade fantástica, ao insólito, colaboram para o entendimento da irrealização de Elias enquanto musicista e enquanto ser humano feliz, pois podemos interpretar que parte de sua constituição não é deste mundo, não podendo ser também a sua felicidade possível neste plano terreno. Se, em um romance realista, o narrador pode buscar criar uma impressão de realidade por meio do uso de adjetivos e descrições aprofundadas, com referência temporal linear e eventos que se concatenam a partir de causa e efeito, o romance moderno, de acordo com Theodor Adorno (1983), ou romances da Modernidade tardia, rompem com a necessidade de serem fiéis à realidade. Esses romances podem causar certo estranhamento no leitor, em 
UMBACH, R.; PEREIRA, S. - A existência como resultado de acasos

parte pela não concretização do final feliz do protagonista, o que é comum em obras realistas.

O estranhamento causado pelo subtexto do plano fantástico pode desacomodar o leitor, que tem então como opção posicionar-se de forma mais ativa diante do romance, já que está "cara a cara" com o inusitado, com os choques que destroem "no leitor a tranquilidade contemplativa diante da coisa lida" (ADORNO 1983: 61). A obra analisada pode ser comparada a A Metamorfose também por essa característica antirrealista: sobre a novela clássica de Kafka, Adorno atentou para o encurtamento da distância entre o narrador e a ação, proporcionado pelo comentário entrelaçado na ação de tal modo que a distinção entre o que é narrativa e o que é ação das personagens quase desaparece.

Sugerindo que a Modernidade tardia fosse empecilho para a narrativa oral, Adorno afirma que "não se pode mais narrar, embora a forma do romance exija a narração" (ADORNO 1983: 55) e aponta que os romances modernos são reflexo dos tempos, em que já não há experiências a serem transmitidas e o narrador assume a característica de precariedade, não detentor de todas as respostas, sendo sua experiência de narração construída como problemática. Em obras com essa marca antirrealista, o narrador pode ser classificado como incerto ou "precário" também pelo quanto está envolvido ou ciente dos acontecimentos. Assim, o insólito em Quem ama não dorme traduz a precariedade da Pós-Modernidade ou da Modernidade tardia em que o autor constrói o romance, na década de 1990, transpondo para a história ambientada no século XIX a quebra dos padrões realistas. Esse movimento resulta no irônico, porque o século XIX foi o auge das narrativas realistas, carregadas de descrições que visavam assemelhar-se à realidade o máximo possível.

A ironia é, aliás, outra característica da narrativa pós-moderna presente em Quem ama não dorme. Ela aparece como elemento que não afirma preceitos morais, mas relativiza visões de mundo para que o leitor encontre sua própria opinião. Por exemplo, o contexto social em que Elias nasce não estimula e ainda impede seu desenvolvimento pessoal, e o narrador reforça essa questão junto ao leitor por meio da estratégia de narrar com ironia. Como no fragmento em que acontecimentos inexplicáveis provocam alterações visíveis em Elias e "[a]lgumas mulheres quase se permitiram pensamentos de soberba, congratulando-se com o fato de terem presenteado os respectivos maridos com um mero mongolóide em lugar de um demônio com olhos cor de urina de vaca" 
UMBACH, R.; PEREIRA, S. - A existência como resultado de acasos

(SCHNEIDER 1999: 36). Outra ironia no texto é a do irmão de Elias com problemas mentais ser uma das personagens que melhor demonstra capital afetivo, o que poderia ser associado a alguém com pleno uso da capacidade mental ou cognitiva. O romance como um todo pode ser lido sob a luz da ironia, já que um ser talentoso e superior é abafado na ignorância e monotonia do vilarejo que o maltrata e não o merece, e o mundo deixa de conhecer esse talento porque um local diminuto o conduz a uma existência desastrosa.

Como bem aponta Jutta Landa (1996: 161), Schneider representa o povoado como "incubador da violência, da teimosia e do fanatismo religioso". Fechado em si mesmo e sem abertura para a diferença, o morador do local não sabe como lidar com Elias e o empurra para a margem. É irônico e triste que nesse ambiente impregnado de violência e embotamento nasça uma criança dotada de talento extraordinário e de uma sensibilidade ímpar. E é paradoxal que, apesar da socialização no marco da violência, a sensibilidade tenha permanecido pura no protagonista. Uma possível explicação é de que a natureza é alheia ao que a humanidade entende por organização ou mérito, o que reforça a perspectiva da ironia como uma das chaves de leitura deste romance. O fato de a obstinação silenciosa da natureza falar mais alto que o brilhantismo de Elias para a música encerra outra contradição e ironia dentro do romance. Ao longo de toda a obra, som e silêncio travam um embate, como no fragmento já citado, no qual, assim que Deus, por meio da natureza, revela a Elias o mundo dos sons, faz-se no rapaz silêncio, mas sobre ele não cessa o ruído provocado pela curiosidade do povoado e pela violência doméstica.

A presença constante da violência e da morte na vida das personagens deve-se, em parte, à época em que a história está ambientada, o início do século XIX, com as altas taxas de mortalidade existentes então, e também às limitações socioespaciais da aldeia de Eschberg, encravada entre as montanhas, mas sobretudo à ignorância e brutalidade da população endogênica, composta em sua maioria de habitantes rudes e cruéis, que não conseguem se articular por meio do uso significativo da linguagem e se comunicam de forma quase animalesca, por grunhidos, gritos e choros. A impossibilidade de articulação dessas personagens em determinados momentos se combina com a violência física, uma violência tão brutal que pode ocasionar mutilações nas vítimas, por exemplo na aplicação de castigos, como no caso do primo de Elias, Peter, que, por ter roubado alguns doces, teve seu braço aleijado. Atos violentos, por vezes de vingança exacerbada, promovem a barbárie no local, substituindo a linguagem e, dessa forma, gerando silêncio e submissão. 


\section{A identidade do protagonista}

A sensibilidade de Elias contrasta com a brutalidade de sua família e dos demais habitantes de Eschberg. Nesse espaço, a violência aparece em diferentes instâncias, como a violência da natureza para com os seres humanos que tentam se estabelecer no local e são assolados por ventos, incêndios e invernos rigorosos. Há violência no tratamento mesquinho entre os vizinhos e na negligência dos adultos para com as crianças. E há também a violência simbólica da igreja enquanto instituição que interfere na vida privada e atua como censora dos costumes.

Em contrapartida, apesar de nunca ter recebido atenção e afeto, Elias cresce generoso e atento às necessidades dos demais, sendo capaz de captar a beleza da natureza e da música e é o único a desenvolver amizade com o irmão doente. O protagonista é considerado um ser exótico, negligenciado pela família e pela comunidade, todos surdos ao seu talento. Ele nasce humanizado no sentido do desenvolvimento empático ao outro, mesmo sendo a humanização algo que não nasce pronta em cada indivíduo. O mais natural é que os indivíduos nasçam semelhantes a animais, focados nas necessidades de sobrevivência, e desenvolvam as características de humanidade a partir de trocas afetivas. Essas características que tornam os seres mais humanos precisam ser desenvolvidas, como habilidades a serem lapidadas com a convivência em sociedade: o desenvolvimento do respeito, do afeto e da empatia. A música ajuda no processo de humanização de Elias, e uma vez que a musicalidade é um dom que nasce com ele e aflora a partir do fenômeno que acontece aos cinco anos, ele desponta como o ser mais sensível no meio daquela comunidade marcada pela intolerância. Em um espaço em que cada um está vivendo maquinalmente, ocupado somente em sobreviver, Elias destoa por desenvolver por si só características de generosidade e sensibilidade, representadas na aptidão para a música, na capacidade de amar profundamente e no entrosamento surreal com a natureza. Ainda assim, sozinho, o protagonista não alcança romper as determinações do ambiente preconceituoso e obediente à igreja para se desenvolver plenamente. O apontamento de Walter Benjamin em "Sobre o conceito de história” de que a felicidade está vinculada ao contexto sócio-histórico no qual o indivíduo está inserido pode explicar o fracasso de Elias em ser feliz: "nossa imagem da felicidade é totalmente marcada pela época que nos foi atribuída pelo curso de nossa existência” (BENJAMIN 1994: 222).

Pandaemonium, São Paulo, v. 23, n. 39, jan.-abr. 2020, p. 111-127 
UMBACH, R.; PEREIRA, S. - A existência como resultado de acasos

Além do talento de musicista, as qualidades de Elias transparecem na forma como estabelece relações com as outras pessoas, que difere dos demais relacionamentos no vilarejo, marcados pela inveja e pela ausência de empatia. Mesmo apreendendo o mundo pela audição, o protagonista desenvolve afeto pelo pai, que quase não fala, em mais uma representação do contraponto silêncio/som no romance. E morre quando compreende a incapacidade de viver seu amor por Elsbeth, que é tão "indizível" quanto seu dom para a música, uma vez que quase não é perceptível aos outros. Apesar de a audição ser o sentido mais desenvolvido em Elias, ele se vale do olfato para "sentir" aqueles que ama: sente-se seguro com o cheiro do pai no chapéu e sonha, não com o perfume, mas com o cheiro mais provável que devem ter os cabelos da amada, conforme mostra o fragmento: "Elias sentiu desesperada coragem para lhe acariciar os cabelos. E depois de o fazer não lavou a mão até perder vestígios do cheiro a curral das suas madeixas" (SCHNEIDER 1999: 89).

\section{Diferentes níveis de realidade}

A literatura da Pós-Modernidade permite contrapor diferentes níveis de realidade. Em Quem ama não dorme, há o desenvolvimento diegético da saga de uma comunidade que sobrevive em um vilarejo inóspito por várias gerações, a história de um ser possivelmente sobrenatural experienciando uma realidade única e praticamente desprovida de laços afetivos e, ainda, o nível de encenação da voz narrativa, refletindo sobre o seu lugar de fala de forma metarreflexiva. Sobre essa última estrutura enunciativa do romance de Schneider, o narrador mostra-se abertamente favorável ao protagonista e desinteressado por outras personagens, como o irmão mais velho de Elias, de quem diz que nada disse, e mesmo que tivesse dito, não teria importância. Além de expressar opinião e ser afeiçoada a Elias, a voz narrativa demonstra o desejo de contar algo mais positivo sobre ele, apesar de manter o curso da história ironicamente sobre a "vida miserável" do protagonista e sobre como ele chegou a uma "espetacular morte". O posicionamento por parte do narrador deixa claro que há uma mediação entre esse elemento da narrativa e o leitor, porque narra a partir de determinado ponto de vista. Assim, a visão do narrador não é completa e seu discurso não apreende todas as facetas da história, mas narra a partir da perspectiva de alguém que acompanha e torce por Elias, descrevendo-o como "uma criança de seu tempo", que "amava tudo o que podia associar-se com a morte", conforme já apontado por Lars Schmeink (2004: 50).

Pandaemonium, São Paulo, v. 23, n. 39, jan.-abr. 2020, p. 111-127 
UMBACH, R.; PEREIRA, S. - A existência como resultado de acasos

Já na família Alder, predomina a falta de afeto, principalmente por parte da mãe. A maioria das mulheres do vilarejo é cruel, mesmo com a própria prole. As casadas assumem o nome do marido renunciando à individualidade, e as solteiras são estigmatizadas pelo perigo que representam, por estarem livres da tutela de algum homem e mais propensas a seguir opiniões próprias. Apesar de assíduo à igreja, o grupo comunitário de Eschberg é intolerante e mau com tudo que lhe parece diferente. Uma das formas de expressão dessa maldade é no trato às mulheres solteiras, às que têm dons especiais e às prostitutas, que são punidas com um banco desconfortável bem à frente na igreja, para que fiquem expostas por suas diferenças e seus erros, medida essa pensada não pelos homens, mas pelas conservadoras senhoras casadas. No grupo de mulheres punidas, que não obedecem a todas as normas da igreja ou não internalizam as leis da sociedade patriarcal, destaca-se a personagem Burga, que diverge da maioria das outras mulheres do local pela liberdade com que administra seu corpo e desejos.

Nenhuma mulher desse espaço, nem a mãe de Elias, introduz o protagonista a um universo de relações afetivas ou de conciliação entre desejo e sentimentos. Elas não se solidarizam com ele por ser uma criança diferente e o veem como objeto de desejo já a partir da puberdade precoce, o que denota insensibilidade quanto a seu estado anômalo. Apesar de Elsbeth nutrir algum carinho por Elias, também ela não tem exemplos de como administrar os sentimentos e abandona essa admiração por um casamento prático.

\section{Apreensão do mundo pelas palavras}

É irônico que, apreendendo o mundo pela audição, Elias tenha sua felicidade em grande medida impossibilitada pela ausência de comunicação, o que pode ser algo audível. Assim como o seu dom não é percebido ou estimulado por desatenção, inveja e falta de verbalização a respeito desse talento para além da aldeia, também o desejo de Elsbeth por ele passa despercebido pela falta de diálogo, problema crônico na comunicação entre os Alder: "Nunca um Alder seria capaz de confessar o seu amor por outra pessoa. Tudo tinha de ocorrer sem recurso às palavras e, caso tal sucedesse, não passariam de meras alusões e meias palavras. Esta gente era muda, muda até a morte" (SCHNEIDER 1999: 119). A mudez e o silêncio são indicadores da impotência, desamparo e ausência de perspectivas diante da opressão que reina no vilarejo, cujos habitantes se movem entre a culpa e o castigo. E, levando-se em conta o papel da linguagem na formação da identidade, 
UMBACH, R.; PEREIRA, S. - A existência como resultado de acasos

percebe-se que a mudez das personagens resulta de sua subjugação diante da violência, que as impede de compartilhar com os outros seus sentimentos, incapacitando-as, também, ao pleno desenvolvimento da sua identidade e de seus laços afetivos.

Essa impossibilidade de expressar-se por meio da linguagem remete à constatação de Adorno (1983) de que o romance, enquanto forma narrativa, depois de a humanidade ter experimentado maldade e violência em guerras mundiais, não teria mais a possibilidade de relatar determinados conteúdos. Em função da provável consciência dos narradores da Modernidade tardia sobre a fragmentação do mundo, os textos se apresentariam de forma lacunar. É o que acontece com este romance de Schneider, em que a dificuldade do relato está tanto na forma lacunar do texto em que nem tudo se explica quanto no universo diegético, no qual as personagens não conseguem se expressar com palavras porque a linguagem não alcança apreender e explicar determinados significados ou sentimentos. A linguagem inarticulada e descuidada frequente em obras pós-modernas pode intentar minimizar as mensagens, as "cargas" da língua, indicando incapacidade da linguagem para expressar significados profundos ou para ter estatuto de verdade.

Uma das personagens que mais interage com Elias é o primo, Peter, que, como ele, também não desfrutou de uma socialização afetiva saudável, considerando o suporte afetivo dos pais e orientação para que os filhos adentrassem a maturidade com segurança em expressar sentimentos e emoções. Nascidas no mesmo dia, essas personagens configuram-se uma como o contraponto da outra, na medida em que Elias exercita sensibilidade e compaixão e Peter apreende apenas o princípio da indiferença e da rejeição, o qual transparece em maus-tratos aos animais. Enquanto Elias sofre por ter se tornado adulto antes do tempo, Peter nunca atinge a puberdade e amarga um corpo infantilizado, o que responde respectivamente à capacidade de cada um deles em se autoanalisar e questionar a realidade na qual estão inseridos. Os dois não têm chance de desenvolver relacionamentos, salvo a amizade tumultuosa que os une. Coerente com as características dos romances da Modernidade tardia, não há respostas para todas as questões sugeridas pela obra, o que possibilita ao leitor formar a própria opinião ao passo em que busca preencher as lacunas, como responder por que Elias suporta a crueldade de Peter. Ao invés de uma realidade diegética fechada, o romance de Schneider aponta possibilidades. 
UMBACH, R.; PEREIRA, S. - A existência como resultado de acasos

É estranho que mesmo ciente das atitudes criminosas do primo, Elias o acompanhe. Mas há entre eles uma ligação que também pode ser considerada da esfera do realismo fantástico. Peter é o único a reconhecer e incentivar o talento desse ser extraordinário, por quem é apaixonado: "Peter foi a única pessoa que, no tempo de vida de Elias, reconheceu o seu gênio. Pressentiu que Elias fora dotado de algo grandioso" (SCHNEIDER 1999: 40). Quando Elias morre, Peter sofre uma transformação em direção a se tornar uma pessoa melhor, como se houvesse então encontrado um ponto de equilíbrio entre a negatividade dele e a positividade de Elias. É como se o primo fosse o extremo do bem e ele o extremo do mal, sendo os dois criaturas destoantes e frutos de ironia divina, na forma como é representada a instância divina neste romance. Nenhum dos dois consegue êxito no desenvolvimento dos seus amores, em grande parte por não terem tido exemplo de laços afetivos nas respectivas famílias e no espaço em que vivem, mas contam um com o outro ao longo de toda trama.

A igreja ajuda na máquina de indiferença e de silenciamento dos dons de Elias. A representação da instituição no vilarejo é de uma igreja parcial, que utiliza seu poder para disciplinar a comunidade através do corpo, do sexo, da política do prazer. A partir de princípios de inclusão e exclusão, a igreja mantém o controle sobre a comunidade, e a influência do cura sobre as famílias ultrapassa a de um guia religioso. Mais que a intenção de guiar espiritualmente, o cura (também chamado Elias) faz do púlpito um palco particular, e da prédica um show de imposição de medo para manter os fiéis pontuais com o pagamento do dízimo, instrumentalizando as emoções de uma comunidade pouco instruída. Portanto, a igreja, através de seu representante, colabora para a desestruturação emocional de Elias por ser corrupta e negligente, e por não cumprir a missão de orientar os desamparados, reforçando a característica de uma sociedade humanamente pouco desenvolvida.

De acordo com Pierre Bourdieu (1996), que cunhou o conceito de "violência simbólica", ela equivale ao processo pelo qual a classe com a possibilidade de dominação econômica ou cultural impõe um conjunto de regras aos dominados. A violência simbólica se expressa na imposição "legítima e dissimulada" de interiorização da cultura dominante. Como essa interiorização se dá como um processo gradual, parte dos dominados podem tomá-la por natural e inevitável. Essa violência simbólica é exercida em Eschberg pela instituição religiosa, representada pelo cura com seus sermões 
UMBACH, R.; PEREIRA, S. - A existência como resultado de acasos

eloquentes, na interferência na vida privada e pela sugestão de sua conduta leviana para com as mulheres.

Um dos efeitos da violência simbólica é a transfiguração das relações de dominação e de submissão em relações afetivas, a transformação do poder em carisma ou em encanto adequado a suscitar um encantamento afetivo. [...] A violência simbólica é essa violência que extorque submissões que sequer são percebidas como tais, apoiando-se em "expectativas coletivas", em crenças socialmente inculcadas. (BOURDIEU 1996: 170171).

Independente da igreja, Deus é representado em Quem ama não dorme no mesmo sentido da natureza: poderoso e indiferente ao sofrimento humano. Dessa forma, permite o nascimento do talentoso Elias em um espaço onde não poderia amadurecer como artista porque é um Deus indiferente e cruel, e age como a natureza, onde é possível que às vezes exista uma flor nascendo por acaso em uma brecha no asfalto. Visualizado por Elias como uma criança sem umbigo porque não nasceu de ninguém, não foi gerado por outro ser com quem estabelecesse afeto, Deus não demonstra simpatia ou compaixão e, apesar de atender ao pedido do musicista para deixar de amar Elsbeth, não articula essa graça de forma a deixá-lo em paz. Irônico, o narrador apresenta essa instância divina como a representação do mal sobre a humanidade, especialmente sobre Elias, como se ele fosse o escolhido para satisfazer o masoquismo divino: "Mas Deus, na sua infinita crueldade, não cessava de o expor à revelação" (SCHNEIDER 1999: 33) e "Johannes Elias Alder apaixonou-se pela sua prima Elsbeth Alder. Estava destinado a apaixonar-se, pois Deus estava ainda longe de acabar com ele" (SCHNEIDER 1999: 70). A crueldade com que o divino é representado pode chocar o leitor predisposto a amalgamar Deus à ética e à beleza. Walter Benjamin atribui à estética romântica a fusão desses conceitos: "Enquanto estrutura simbólica, supunha-se que o belo se fundia com o divino, sem solução de continuidade. A noção da imanência absoluta do mundo da ética no mundo do belo foi elaborada pela estética teosófica dos românticos” (BENJAMIN 1984: 182).

Mas o romance analisado propõe uma visada distorcida do que poderia ser o esperado pelos leitores: pela ótica do narrador, o que Deus faz com Elias é torná-lo feio e repugnante aos olhos dos outros, enquanto o preenche de um amor imenso, que nunca se concretiza. O narrador aponta ainda a predisposição para se apaixonar como crueldade divina, na qual os humanos são joguetes, apaixonando-se somente para necessariamente sofrer e assim divertir a esse Deus. 
UMBACH, R.; PEREIRA, S. - A existência como resultado de acasos

Cansado das decepções que a vida lhe impõe, Elias concentra sua energia emocional em evitar dormir. Faz isso possivelmente como forma de sublimar o medo de outros sofrimentos que poderiam estar reservados a ele. O porquê de tal atitude é mais uma das lacunas que o leitor deve preencher nesse romance que não oferece respostas prontas. Ciente de que não descansar o levaria à morte, Elias deixa de dormir justamente quando recebe aplausos pelo talento como musicista em uma cidade maior. Talvez por perceber que, por mais virtuoso que fosse, todo sucesso advindo da música não supriria a falta do amor de Elsbeth, agora casada. Tanto o sono quanto a morte remetem à parada ou congelamento do tempo, e assim a intenção de Elias pode ser vista como uma tentativa de se sobrepor ao curso temporal. A morte e o sono, ou a resistência a ele, constituem temas centrais do romance, já sinalizados no título original da obra, "Schlafes Bruder" (“Irmão do sono"), uma referência a figuras da mitologia grega na qual o irmão gêmeo de Hipnos, deus do sono, é Tânatos, deus da morte. Em uma trama complexa que interliga elementos como fogo, nascimento, amor e estranheza, encontram-se várias metáforas associadas à morte, evidenciando sua "onipresença" na vida das pessoas de Eschberg, como assinala Schmeink (2004: 48). Imagens antigas que simbolizam a morte, como a da borboleta-limão, surgem ao longo do romance em associações temáticas diversas.

A realização do anseio de ter o talento reconhecido, de certa forma, esvazia o sonho de conteúdo, o que poderia levar à reflexão de que a vida, para Elias, só teria finalidade e sentido enquanto as aspirações não se realizam. Ou ainda, todas essas hipóteses acerca da motivação do protagonista para suicidar-se de maneira sofrível podem estar relacionadas à característica dos textos pós-modernistas em oferecer elementos que mantenham o leitor focado no texto em si, frustrando a tendência natural dos leitores de buscar no texto significados prováveis. Quando decide não mais dormir para amar plenamente, Elias já não vê nenhum sentido existencial, que ele vislumbra somente no amor. O protagonista então se aproxima do que Adorno definiu como “[o] sujeito literário, quando se declara livre das convenções da representação do objeto, reconhece ao mesmo tempo a própria impotência, a supremacia do mundo das coisas” (ADORNO 1983: 62).

\section{Considerações finais}

Condensando características da literatura pós-moderna, Robert Schneider constrói em Quem ama não dorme um romance crítico às sociedades mesquinhas que não concedem 
UMBACH, R.; PEREIRA, S. - A existência como resultado de acasos

chances a quem é diferente e tornam-se mais cruéis que a própria natureza, que parece cruel por ser indiferente à condição humana. A crítica se estende à igreja enquanto instituição de valores que podem ser distorcidos e que pode falhar em refletir sobre o princípio do bem comum.

Apesar da crítica social do autor e de o protagonista não alcançar realização nem na carreira nem no campo do amor, o romance não encerra uma mensagem pessimista, dado que o vilarejo de pessoas mesquinhas tem sua indiferença punida, de certa forma, ao desaparecer consumido pela voracidade da natureza. Ou seja, independentemente de quanta mesquinhez ou de quanto sofrimento um espaço presencia, todos os indivíduos que por ali passam, bons e maus, realizados e frustrados, talentosos e inaptos, todos desaparecerão. E a natureza, como força avassaladora, retorna paciente e democraticamente à superfície. $\mathrm{O}$ aniquilamento de Eschberg aponta a ruptura dessa fase em que a comunidade é vinculada à barbárie e permite que o futuro possa ser pensado como um processo aberto, diferente do presente diegético. O narrador faz então uma correlação entre o sonhar e o sentido da vida:

Não há esperança que tenha sentido. Que ninguém pense realizar os seus sonhos. Mais do que isso, deverá compreender como é loucura ter esperança. Uma vez isso compreendido, pode então ter esperança. Se, mesmo assim, conseguir ainda sonhar, então a vida tem um sentido. (SCHNEIDER 1999: 118).

Talento e amor são duas grandezas de ordem distinta. No romance de Schneider, ambas estão condicionadas ao outro, não bastando por si para culminarem na felicidade e realização plena do ser que as possui. Falta-lhes o complemento da aceitação e compreensão alheia. Essa ideia leva à hipótese de que, enquanto seres, estamos inevitavelmente vinculados uns aos outros, assim como a humanidade está vinculada ao espaço natural que habita. Depois de gerações de confrontos com a natureza para se estabelecer no povoado de Eschberg, a natureza vence a obstinação humana e a vida daquele grupo mesquinho ali já não é possível.

A intertextualidade e a configuração pós-moderna do romance ajudam a entender os obstáculos à não realização desse protagonista, uma vez que representam a fragmentação em um contexto marcado pela depreciação de valores que, para Elias, são inatos. Não há possibilidade de felicidade para a delicadeza que nasce em meio à brutalidade. O romance analisado suscita questionamentos para os quais o leitor não encontra respostas prontas, como por que Elias mantém-se amigo de Peter; por que ele decide não mais dormir para expressar seu amor em tempo integral, sendo que nunca 
UMBACH, R.; PEREIRA, S. - A existência como resultado de acasos

comunicou esse amor verbalmente a Elsbeth; qual a função das personagens secundárias, apresentadas brevemente pelo narrador, na composição do enredo; e por que o cura Elias, ao adivinhar a paternidade do menino Johannes Elias Alder, fica transtornado e se joga de um penhasco, lembrando o comportamento também suicida e enigmático da esfinge tebana na peça Édipo Rei, de Sófocles, sendo que no texto de Schneider há a suposição de que o religioso era pai de muitas outras crianças da aldeia e convivia bem com essa situação. É possível concluir que Schneider escreve Quem ama não dorme de forma ensaística, considerando as características que Adorno (1994) atribui para a forma ensaio, como uma narrativa que não inicia pelo começo e não segue a história cronologicamente, não apresenta conceitos fechados, permitindo que o leitor tenha liberdade de interpretação, e não apresenta uma conclusão. Conforme Adorno, “o ensaio não almeja uma construção fechada, dedutiva ou indutiva" (ADORNO 1994: 174).

A história de Elias Alder permite a reflexão de que o sucesso de uma existência não depende somente da determinação individual, ou ainda de talento gigantesco e de sensibilidade inata, mas é antes o resultado de acasos, como os que determinaram o nascimento dele em Eschberg e o fato de Lucas ter comunicado a intenção de casar a Elsbeth antes que ela e o protagonista pudessem verbalizar a simpatia mútua. Essa ideia de que nem tudo possui sentido ou propósito está expressa também no final aberto em que Elsbeth, agora Lukasina, porque atende pelo nome do marido, não sabe colocar a grandiosidade do amor em palavras, mas ainda assim é prática em constituir uma família, enquanto Elias, interessado em expressar musicalmente a beleza dos sentimentos, mostrase não adaptado à vida:

As crianças olhavam-na com os seus olhos redondos castanhos. Então Cosmas, o mais velho, dirigiu-se à mãe e perguntou com voz adulta, desafinada: "Senhora minha mãe, que quer dizer amor?"

"Que quer dizer amor?", riu Lukasina; beijou o brilhante narizinho abatatado do filho e puxou-lhe o capuz para a cabeça. É que começara de novo a chover. (SCHNEIDER 1999: 178).

A atitude de Elsbeth remete à praticidade em detrimento da contemplação melancólica a que se lançou Elias, e acentua o contraste entre quem age e quem reflete: sugere que a ação, o fazer é a ligação primitiva com a realidade e, portanto, o caminho certo e puro. Em contrapartida, o pensamento, a reflexão, a sabedoria podem se revelar traiçoeiros e enlouquecedores. O que para Adorno (1994) é o autêntico tema da forma ensaística, compõe-se como cerne do enredo de Quem ama não dorme: a relação entre a 
UMBACH, R.; PEREIRA, S. - A existência como resultado de acasos

natureza e a cultura. Há ainda outra ironia contida nesse final: a criança, que será o último Alder a habitar o vilarejo, lembra o protagonista pela voz destoante nos primeiros anos da infância.

Elias não se realiza enquanto artista ou no plano sentimental por vários motivos: ele nasce em meio a uma comunidade intolerante com as diferenças e despreparada para prover as crianças de uma educação emocional, que é assim porque exercita a mesquinhez ao invés da compaixão e tem na igreja uma chave reguladora das mentalidades, de modo a distorcer os valores realmente importantes para desenvolver o humano em cada indivíduo e dotar de sentido a existência. O romance contém a ideia de que a vivência pode ser compreendida como resultado de acasos, não apenas planejamento e determinação pessoal. Mas, ainda que talento e amor não bastem, há esperança para quem se propõe a compreender e persistir no sonho. É preciso, portanto, contra toda correnteza vil do acaso, um posicionamento ativo e certa dose de sorte na economia de chances para que prosperem os sonhos e que se veja sentido na vida.

\section{Referências bibliográficas}

ADORNO, Theodor W. Posição do narrador no romance contemporâneo. In: BENJAMIN, Walter; HorkheIMER, Max; AdORno, Theodor W.; JuRGEN, H. Textos escolhidos. Tradução de Modesto Carone et al. São Paulo: Abril Cultural, 1983, p. 269-273. (Os Pensadores).

ADORNO, Theodor W. O ensaio como forma. In: COHN, Gabriel (org.). Theodor W. Adorno. Tradução de Flávio Kothe. São Paulo: Ática, 1994, p. 167-187.

BENJAMIN, Walter. Alegoria e drama barroco. In: BENJAMIN, Walter. Origem do drama barroco alemão. Tradução de Sérgio Paulo Rouanet. São Paulo: Brasiliense, 1984, p. 181-211.

BENJAmin, Walter. Sobre o conceito da História. In: Benjamin, Walter. Magia e técnica, arte e política: ensaios sobre literatura e história da cultura. Tradução de Sérgio Paulo Rouanet. São Paulo: Brasiliense, 1994, p. 222-232.

BouRdieu, Pierre. Razões práticas: sobre teoria da ação. Tradução de Mariza Corrêa. Campinas: Papirus, 1996.

GoETHE, Johann Wolfgang. Die Leiden des jungen Werthers. Stuttgart: Reclam, 1977.

KAFKA, Franz. A metamorfose. Tradução de Marcelo Backes. PortoAlegre: L\&PM Pocket, 2016.

LANDA, Jutta. Robert Schneiders "Schlafes Bruder": Dorfchronik aus Kalkül? Modern Austrian Literature, Nebraska, v. 29, n. 3-4, 1996, p. 157-168. Disponível em: http://www.jstor.org/stable/24648653. Acesso em: 5 maio 2019.

MORITZ, Rainer. Erläuterungen und Dokumente zu Robert Schneider: Schlafes Bruder. Stuttgart: Reclam, 1999.

MORITZ, Rainer. Über “Schlafes Bruder”: materialien zu Robert Schneiders roman. Leipzig: Reclam, 1996. 
UMBACH, R.; PEREIRA, S. - A existência como resultado de acasos

SCHMEINK, Lars. Hypnos und Thanatos: das bild des todes in Robert Schneiders Schlafes Bruder. Modern Austrian Literature, Nebraska, v. 37, n. 3-4, 2004, p. 47-64. Disponível em: https://www.jstor.org/stable/24648972. Acesso em: 5 maio 2019.

SCHNEIDER, Robert. Quem ama não dorme. Tradução de Maria João Cordeiro. Lisboa: Temas e Debates, 1999.

Recebido em 25 de junho de 2019 Aceito em 3 de setembro de 2019 